\title{
場所打ち杭の引抜き抵抗に関する解析
}

\section{AN ANALYTICAL STUDY ON UPLIFT BEHAVIOR OF CAST-IN-PLACE CONCRETE PILES}

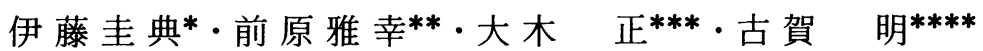 \\ By Keisuke ITOH, Masayuki MAEHARA, Tadashi OHKI and Akira KOGA
}

\begin{abstract}
This paper presents the interrelation between skin friction-strain curves from the results of pull-out tests on cast-in-place piles and stress-strain curves through soil tests. Also presented is a method for simulation of uplift behavior of piles by FEM based on application of those interrelation shapes. The followings are summary results of this study ; (1) FEM is one of the effective methods to predict the uplift behavior of piles and the ground, (2) by analysis, the value of the modulus of deformation can be estimated to be four times $E_{50}$, and (3) tension failure occurs in a truncated cone shape near the ground surface and the shear sliding surface in a cylindrical shape near the pile shaft in the deeper ground.
\end{abstract}

Keywords : cast-in-place pile, pull-out load, stress-strain curve, FEM, sliding surface

\section{1. まえがき}

著者らは前論文 ${ }^{1)}($ 以下本論で使用する「前論文」は すべて文献 1）を指す）で場所打ち杭の引抜き抵抗に関 する基本的特性を現場実験により明らかにした。

しかし，引抜き抵抗機構を解明し，設計の実務へ反映 するためには，なお多くの検討すべき課題が残されてい る. 特に, 杭一地盤系の変形, 破壊機構を明らかにし, 予測することは重要な課題である.

本論文は, 杭の引抜き実験から得られる周面摩擦力 変位の実測值と土質試験から得られる土の応力 ひずみ 曲線との関係を述べこの結果を用いて数值解析を行い, 杭一地盤系の変形, 破壊挙動に関する計算値と実測値と の比較, 予測手法について述べたものである.

\section{2. 杭周面摩擦力と土のせん断変形特性}

杭に引抜き力を与えたときに杭周面に作用する摩擦力 は，周面に接した土のせん断ひずみに対応するせん断応

\footnotetext{
*正会員 東京電設サービス侏開発部 （テ105 港区西新橋 3-20-4)

** 正会員 東京電力(侏)工務部 ( 1100 千代田区内幸町 1-1-3)

*** 正会員 東電設計(侏送変電土木部 （テ105 港区西新橋 1-4-6)

**** 正会員 (侏)奥村組土木技術部（テ107 港区元赤坂 1-3-10）
}

力と考えられている. 杭の変位量が増大し，土のせん断 ひずみが限界値に達すると杭周面あるいは杭近傍の地中 にすべりが生じ，摩擦力は最大值に達する．このような

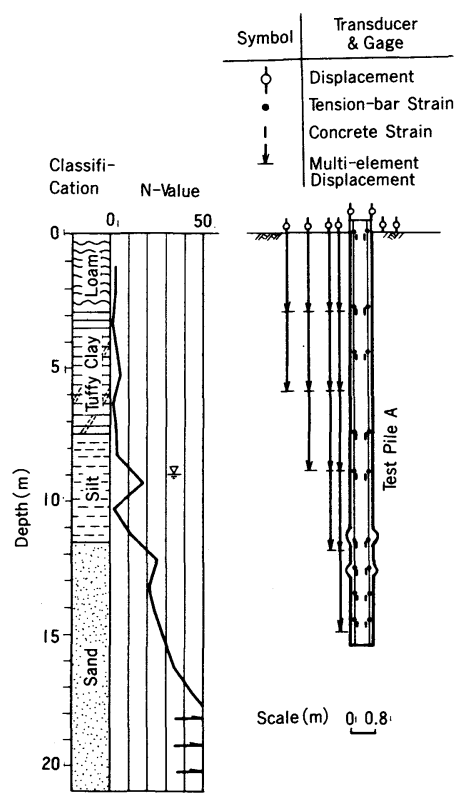

Fig. 1 Boring of site geology, test pile and arrangement of instruments. 
現象は, 実測された周面摩擦力〜変位量曲線から理解で きる. この最大周面摩擦力は, 土質試験から得られる土 のせん断強度で評価できることを前論文で確認した。し かし, 杭の変位量の予測を行うためには, 実測された周 面摩擦力一変位量曲線亡土質試験から得られる土の応力 〜ひずみ曲線との関係を明確にすることが必要である.

ここでは, 前論文で示した場所打ち杭 (半径 $r_{0}=40$

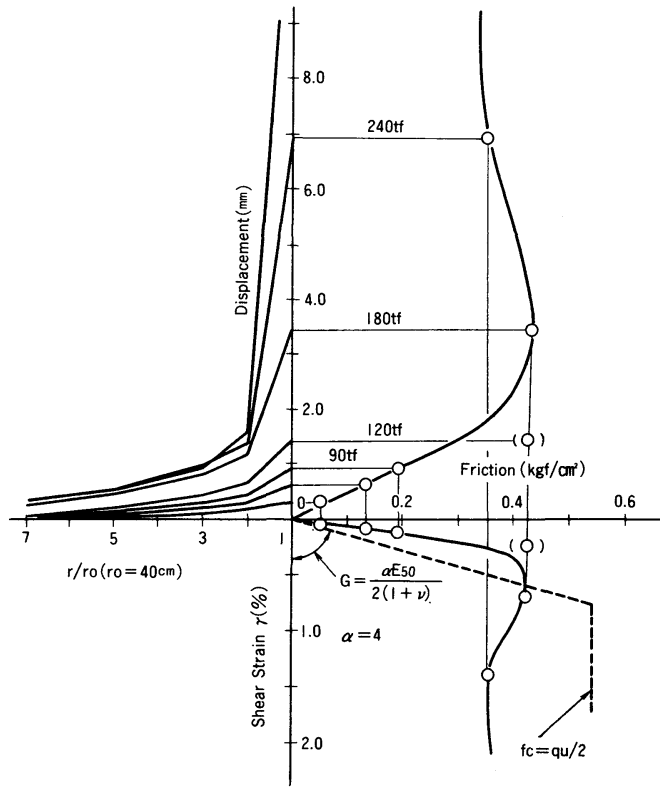

(a) Loam GLO $-2.8 \mathrm{~m}$

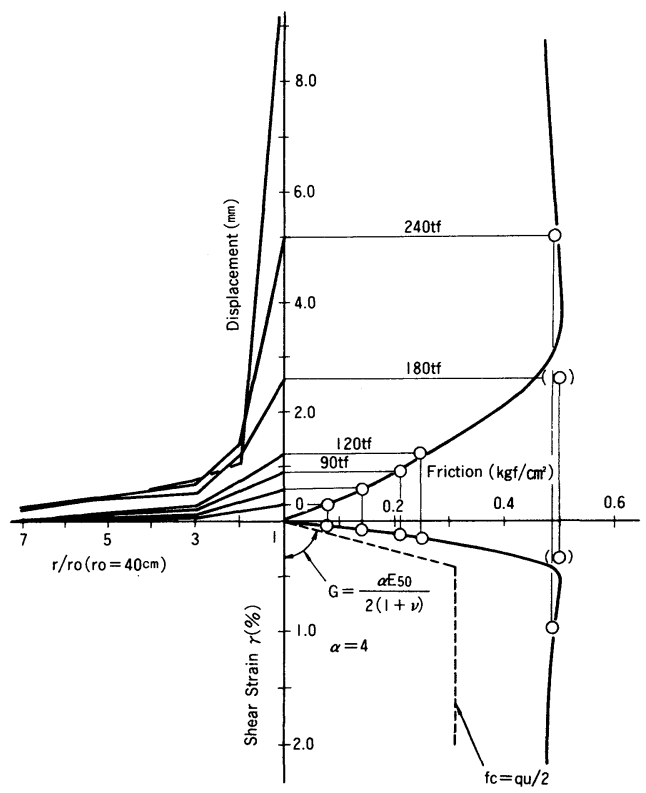

(b) Tuffy Clay GL-2.8 $-9.0 \mathrm{~m}$ $\mathrm{cm} ）$ の周面摩擦力〜変位量曲線および地中変位分布を もとに周辺地盤のせん断変形特性について考察する.

Fig. 1 に対象とした試験杭 A と各種計器および地層断 面を示す．なお，試験杭の形状は，杭を引き揚げて調査 した結果を示している.

Fig. 2 にローム層 (GL $0.0 \mathrm{~m} \sim \mathrm{GL}-2.8 \mathrm{~m})$ ，凝灰質 粘性土層 $(\mathrm{GL}-2.8 \mathrm{~m} \sim \mathrm{GL}-9.0 \mathrm{~m})$ ならびに砂質土 層 $(\mathrm{GL}-12.6 \mathrm{~m} \sim \mathrm{GL}-15.6 \mathrm{~m})$ の実測された周面摩 擦力〜変位量〜ひずみ曲線を示す. 同図において, 第 1 象限は周面摩擦力と変位量の関係を示し, 縦軸に杭の変 位量, 横軸に周面摩擦力を示している. 第 2 象限は地中 の鉛直方向の変位分布を示し, 縦軸に変位量, 横軸に杭 中心からの距離を杭の半径の比 $\left(r / r_{0}\right)$ として示して いる.なお，杭周面に接した土の変位量は杭の変位量に 一致させている. 第 4 象限は摩擦力と土の見掛けのせん 断ひずみ（以下「せん断ひずみ」と表示する）の関係を 示し，縦軸に土の「せん断ひずみ」，横軸に周面摩擦力 を示している.なお，土の「せん断ひずみ」とは，杭周 面 $\left(r=r_{0}\right)$ と周面から $40 \mathrm{~cm}$ 離れた地点 $\left(r=2 r_{0}\right)$ における鉛直変位の差を, その間の距離 $(40 \mathrm{~cm})$ で除 した値としたものである。

ローム層（Fig.2（a)）における各曲線の相互関係を 考察する. 摩擦力一変位量曲線から, 杭の変位量 1.5 $\mathrm{mm}$ (荷重 $120 \mathrm{tf}$ に相当) 以内においては摩擦力は変位 量の増加に伴いほぼ直線的に増大している．これに対応 する地中の変位分布曲線は, 杭周面に向かってなめらか に増加する性状を示し，土と杭周面との境界面には，ず

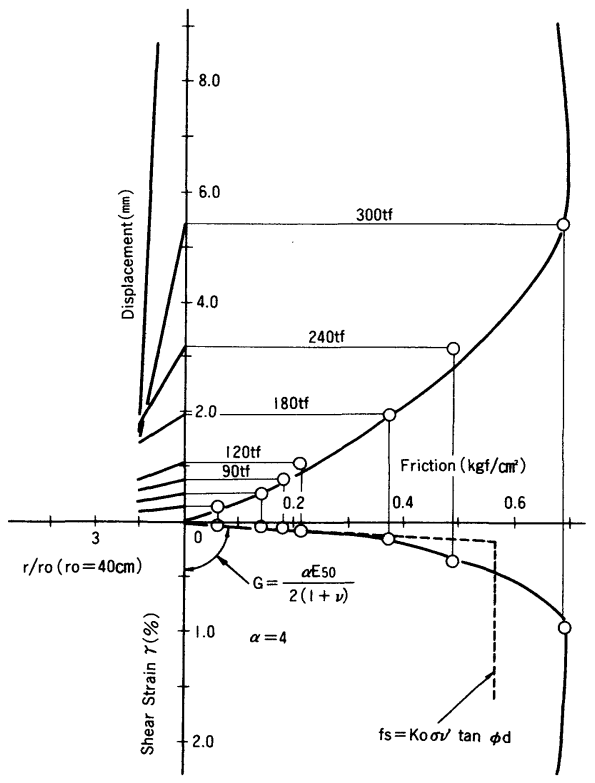

(C) Sand GL-12.6 -15.6m

Fig. 2 Friction $\sim$ displacement $\sim$ shear strain curves: 
れは生じていないと判断される. 杭の変位量が $1.5 \mathrm{~mm}$

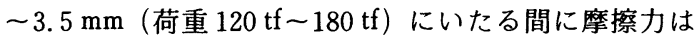
最大に達し, 以後変位量の増加とともに摩擦力は減少し ている.摩擦力が最大になった時点での変位分布曲線は, $r=2 r_{0}$ の地点から杭周面にいたる間に急激に増加して いる. 以後, 杭の変位量が増加しても $r=2 r_{0}$ の地点よ り外側の変位量の増加は認められない. 以上のことから, 杭の変位量が小さいときには, 周辺地盤も杭に追随して 変形し, 変位量が増加し周面摩擦力が最大に近づくと, 杭周面近傍の土にすべりが生じることがうかがえる． 方, 周面摩擦力 一世ん断ひずみ」曲線から，「せん断 ひずみ」の増加に応じて摩擦力が増大し，「せん断ひずみ」 が限界値に達すると破壊に至ることが認められる。

凝灰質粘性土層（Fig.2 (b)), 砂質土層 (Fig.2 (c)) についても同様な性状を示している.なお，「せん断ひ ずみ」の限界値は, 粘性土で $0.5 \sim 0.7 \%$, 砂質土で $1.0 \%$ 程度である. 以上により, 冒頭に述べた土のせん 断ひずみに対応する杭周面の摩擦力特性を検証できたと 考えられる.

次に, Fig. 2 に示した摩擦力〜「せん断ひずみ」曲線 と土質試験から得られる土の応力〜ひずみ曲線との関係 について考察する．同図に示した破線は, 一軸圧縮試験

（粘性土）と三軸圧縮（CD）試験（砂質土）結果を用 いて次式より求めている.

$$
\begin{aligned}
& G=\alpha E_{50} / 2(1+\nu) \\
& f_{c}=q_{u} / 2 \\
& f_{s}=K_{0} \sigma_{v}^{\prime} \tan \phi_{d}
\end{aligned}
$$

ここに，G：土のせん断弾性係数（破線の勾配）

$$
\begin{aligned}
E_{50} & : \text { 土の変形係数 } \\
\nu & : \text { ポアソン比（粘性土 } 0.45, \text { 砂質土 } 0.35) \\
\alpha & \left.: \text { 補正係数 (道路橋示方書 }{ }^{2)}, \alpha=4\right) \\
f_{c} & : \text { 粘性土の最大摩擦力 (破線の上限値) } \\
f_{s} & : \text { 砂質土の最大摩擦力 (破線の上限値) } \\
q_{u} & : \text { 粘性土の一軸圧縮強度 } \\
K_{0} & : \text { 静止土圧係数 }\left(K_{0}=1-\sin \phi_{d}\right) \\
\sigma_{v}^{\prime} & : \text { 有効土被り圧 } \\
\phi_{d} & : \text { 砂の内部摩擦角 }
\end{aligned}
$$

Fig. 2 から，実測された周面摩擦力〜「せん断ひずみ」 曲線と土質試験結果とは比較的よく対応していると考え られる。

\section{3. 現場実験の数値シミュレーション}

ここでは前論文で示した現場実験を有限要素法を用い てシミュレートし, 引抜き抵抗に関する基本的特性を数 値解析的に検証する.

（1）解析条件

杭〜地盤系の応力・変形解析を行う場合，実測された
挙動を忠実に再現できる解析手法を選定することが望ま しい. 杭の形状や複雑な地層構成等を反映できる解析法 としては, 現在のところ有限要素法が最も適していると 考えられる. さらに解析手法の実務への展開を考慮すれ ば，入力条件である材料の応力〜ひずみの関係は，でき るだけ単純なことが必要である.

本解析では，地盤を非線形弾性体として取り扱い, Fig. 3 に示すように応力〜ひずみ関係をバイリニアにモ デル化し，せん断破壊に対してはモール・クーロンの基 準,引張り破壊に対しては引張り強度に従うことにした.

また，2. で述べたように，杭の変位量の小さいとき は周辺地盤も杭に追随して変形し, 変位量の増大に伴い, 杭周面近傍の土ですべりが生じることが明らかになっ た.したがって，このような挙動を解析する場合には, 杭と地盤との不連続変形を考慮することが必要と考えら れる. そこで, 本解析では杭と地盤との境界面に Goodman ら ${ }^{3)}$ が提案しているジョイント要素を使用す ることにした.このジョイント要素は, Fig. 4 に示すよ うに異種材料間に 4 接点を有する厚さのない要素であ り, 各接点間での相対せん断変位と要素内のせん断応力 との関係から定義されるせん断ばね $k_{s}$ および相対垂直 変位と垂直応力との関係から定義される垂直ばね $k_{n}$ か ら成る.なお，ここではそれぞれの変位と応力の関係を

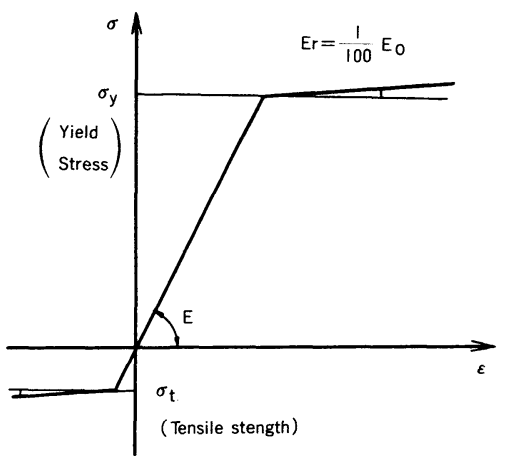

Fig. 3 Elasto-plastic behavior of soil (solid element).

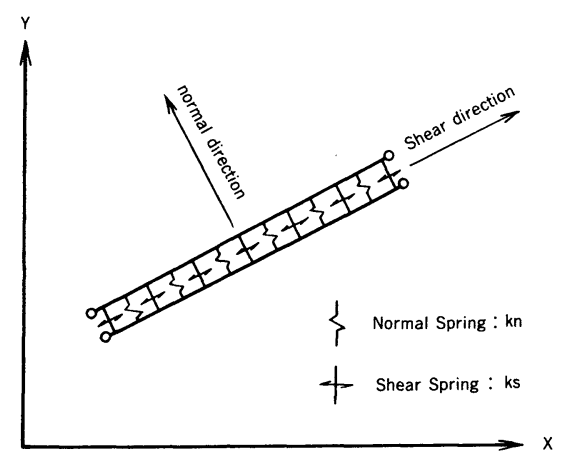

Fig. 4 Joint element. 

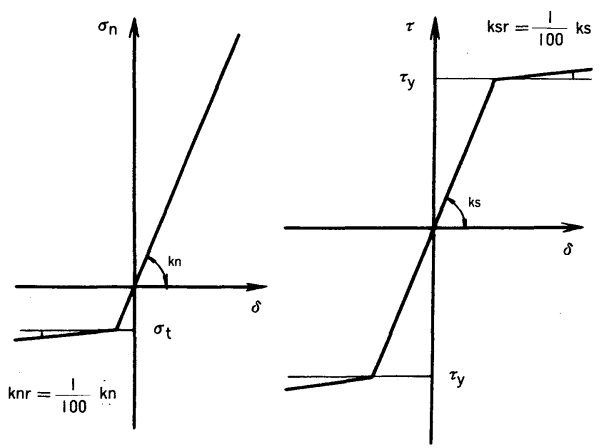

Fig. 5 Elasto-plastic behavior of spring (joint element).

Fig. 5 に示すようにバイリニアにモデル化し, 破壊条件 は地盤と同様にせん断に対してはモール・クーロンの基 準, 引張りに対しては引張り強度に従うことにした，杭 と地盤を軸対称モデルとし, Fig.6に示すような要素に 分割した。地層構成は, 上からローム層, 凝灰質粘土層, シルト層, 砂層の 4 層とした. 杭の形状は実測寸法にで きるだけ近似させた。解析に用いた材料の物性值を Table 1 に示す. なお, 物性値の設定にあたっては, 次 のことに留意した。

a) 地盤の強度定数は, 粘性土に対しては $C=q_{u} / 2$, 砂質土に対しては $\phi=\phi_{d}$ とした。それぞれ，一軸圧縮 試験および三軸圧縮 $(C D)$ 試験から得られる値である. また, 引張り強度 $\sigma_{t}$ は, 文献 4$\left.), 5\right)$ 等を参考にして粘 性土で $\sigma_{t}=0.2 C$, 砂質土で $\sigma_{t}=0$ と仮定した。

b) 地盤の変形係数 $E_{0}$ は， $E_{50}$ を 4 倍した値を採用 した.この值は, 2.で示した実測された周面摩擦力〜「せ ん断ひずみ」曲線と土質試験から得られた応力〜ひずみ 曲線との関係ならびに道路橋示方書等 $21,61,7), 8$ に示され ている一般的な值を考慮して設定した．破壊後の変形係 数 $E_{r}$ は, $E_{r}=E_{0} / 100$ と仮定した。

c) 試験杭は, コンクリートと PC 網棒との複合体 であるので, これを均一材料として取り扱うこととして 弾性係数を算定した。算定にあたり, コンクリートの弾 性係数は，実験から得られた值を用いた。

d）ジョイント部の物性の評価法は，現在のところま だ確立されていないと考えられる。ここでは，実験結果 に基づいて，低い荷重レベルでは杭と地盤との間でのず れは生じないで，荷重が増大し，杭近傍の地盤が破壊に 達してから，顕著なずれが生じるものとした，そこで， $k_{s}, k_{n}$ については, ジョイント部の破壊が生じるまで は，隣接する地盤の剛性に見合った大きな值を仮定し， 破壊後はその $1 / 100$ とした. 強度定数についても, 以上 の考え方から，隣接する地盤と同一とした。

なお，以上の解析（以下不連続解析と称する）のほか に, ジョイント部を有さない, 通常の連続体として取り

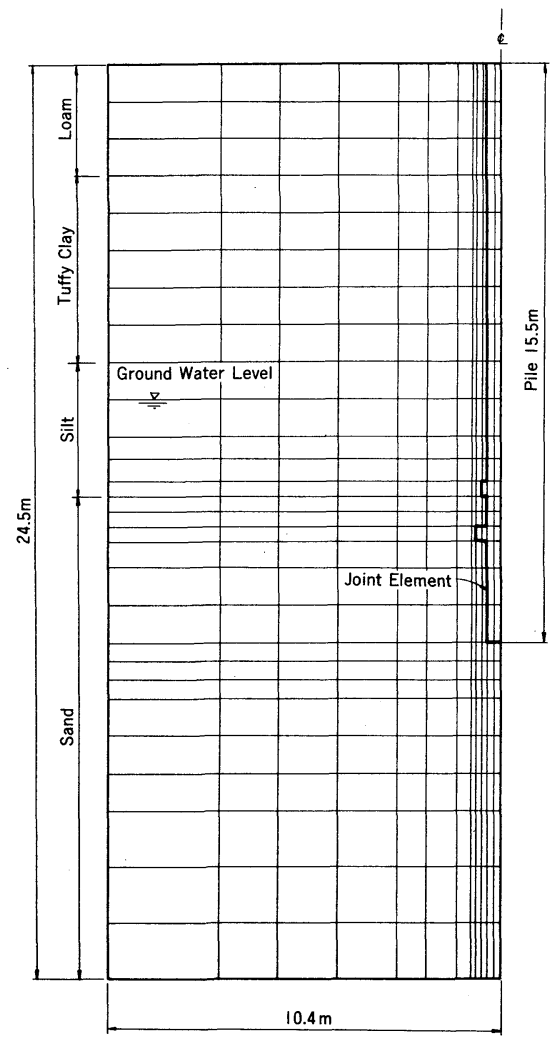

Fig. 6 Finite element mesh.

Table 1 Input material properties.

\begin{tabular}{|c|c|c|c|c|c|c|}
\hline Element & $\begin{array}{c}\text { Material. } \\
\text { Parameters } \\
\end{array}$ & Pile & Loam & $\begin{array}{c}\text { Tuffy } \\
\text { Clay }\end{array}$ & Silt & Sand \\
\hline \multirow{7}{*}{ 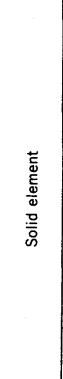 } & $\begin{array}{l}\mathrm{C} \\
\left(\mathrm{kgf} / \mathrm{cm}^{2}\right)\end{array}$ & - & 0.55 & 0.29 & 0.33 & 0.0 \\
\hline & $\begin{array}{l}\phi \\
\text { (degree) }\end{array}$ & - & 0.0 & 0.0 & 0.0 & 40.0 \\
\hline & $\begin{array}{l}\sigma \mathrm{t} \\
\left(\mathrm{kgf} / \mathrm{cm}^{2}\right)\end{array}$ & 19.0 & 0.11 & 0.06 & 0.07 & 0.0 \\
\hline & $\begin{array}{l}\text { Eo } \\
\left(\mathrm{kgf} / \mathrm{cm}^{2}\right)\end{array}$ & $2.4 \times 10^{5}$ & 212.0 & 84.0 & 136.0 & 1000.0 \\
\hline & $\begin{array}{l}\mathrm{Er} \\
\left(\mathrm{kgf} / \mathrm{cm}^{2}\right)\end{array}$ & $1.9 \times 10^{5}$ & 2.1 & 0.8 & 1.4 & 10.0 \\
\hline & $\begin{array}{l}\gamma_{\mathrm{t}} \\
\left(\mathrm{gt} / \mathrm{cm} \mathrm{m}^{\prime}\right)\end{array}$ & - & 1.4 & 1.65 & 0.65 & 0.85 \\
\hline & $\nu$ & 0.17 & 0.45 & 0.45 & 0.45 & 0.35 \\
\hline \multirow{7}{*}{ 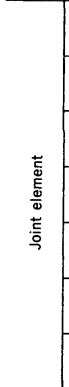 } & $\begin{array}{l}\mathrm{Cj} \\
\left(\mathrm{kgf} / \mathrm{cm}^{2}\right)\end{array}$ & - & 0.55 & 0.29 & 0.33 & 0.0 \\
\hline & $\begin{array}{l}\phi \mathrm{j} \\
\text { (degree) }\end{array}$ & - & 0.0 & 0.0 & 0.0 & 40.0 \\
\hline & $\begin{array}{l}\sigma_{\mathrm{tj}} \\
\left(\mathrm{kgf} / \mathrm{cm}^{\prime}\right)\end{array}$ & - & 0.11 & 0.06 & 0.07 & 0.0 \\
\hline & $\begin{array}{l}\text { ks } \\
\left(\mathrm{kgt} / \mathrm{cm}^{3}\right)\end{array}$ & - & 212.0 & 84.0 & 136.0 & 1000.0 \\
\hline & $\begin{array}{l}\text { ksr } \\
\left(\mathrm{kgt} / \mathrm{cm}^{3}\right)\end{array}$ & - & 2.1 & 0.8 & 1.4 & 10.0 \\
\hline & $\begin{array}{l}\mathrm{kn} \\
(\mathrm{kgf} / \mathrm{cm})\end{array}$ & - & 212.0 & 84.0 & 136.0 & 1000.0 \\
\hline & $\begin{array}{l}\mathrm{knr} \\
\left(\mathrm{kgf} / \mathrm{cm}^{3}\right)\end{array}$ & - & 2.1 & 0.8 & 1.4 & 10.0 \\
\hline
\end{tabular}


扱った有限要素法解析（以下連続解析と称する）も実施 し，両者の比較を行うことにした。

\section{（2）解析結果および実測値との比較}

計算は，荷重を 13 ステップに分割し，1 ステップの 荷重を実験の最小ステップ荷重である $30 \mathrm{tf}(0.29 \mathrm{MN})$ に対応させた。

Fig. 7 に引抜き荷重 $240 \mathrm{tf}(2.35 \mathrm{MN})$ と $360 \mathrm{tf}(3.53$ $\mathrm{MN}$ ) 載荷重時の杭体の軸力分布の計算値を実測值とあ わせて示す，不連続解析結果および連続解析結果とも， 実測値とよい近似を示している.

Fig. 8 に引抜き荷重〜変位量曲線の計算値を実測値と

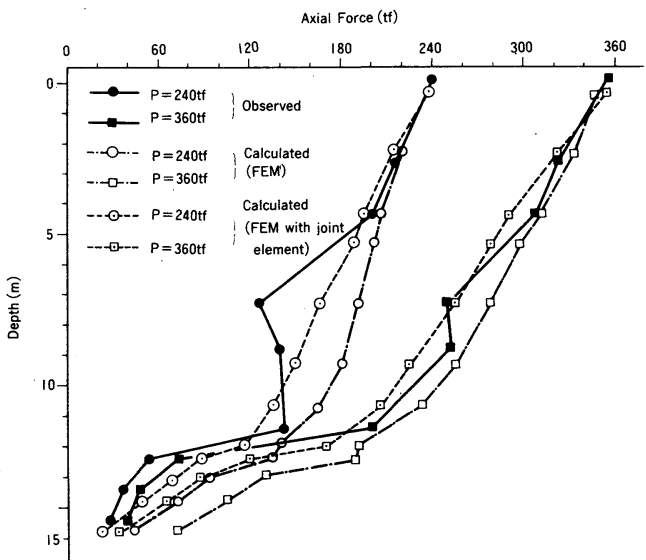

Fig. 7 Comparison of observed and calculated result (distribution of axial force).

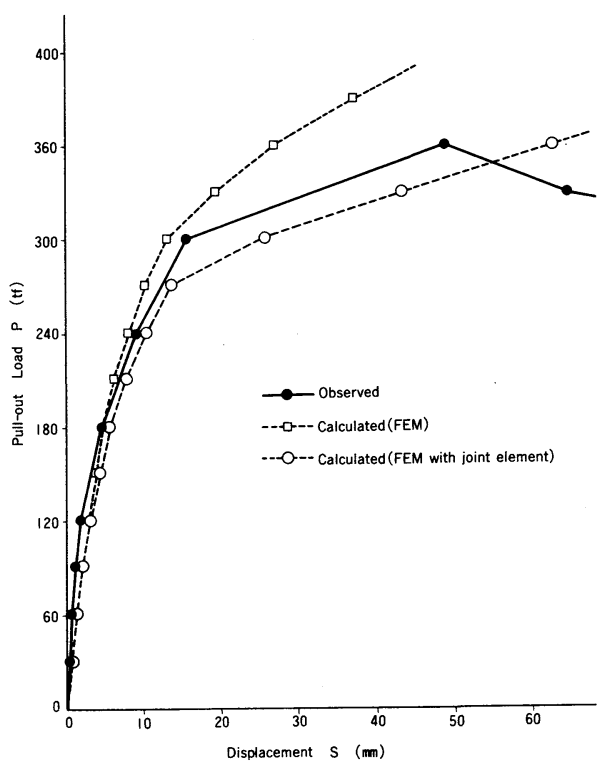

Fig. 8 Comparison of observed and calculated result ( $P$ vs. $S$ curves).
あわせて示す.不連続解析結果および連続解析結果とも, 荷重 $270 \mathrm{tf}(2.65 \mathrm{MN})$ までは, 実測値によく近似して いる. しかし荷重が $270 \mathrm{tf}(2.65 \mathrm{MN})$ を超え，最大荷 重に近づくと，不連続解析結果は実測值に比較的よく近
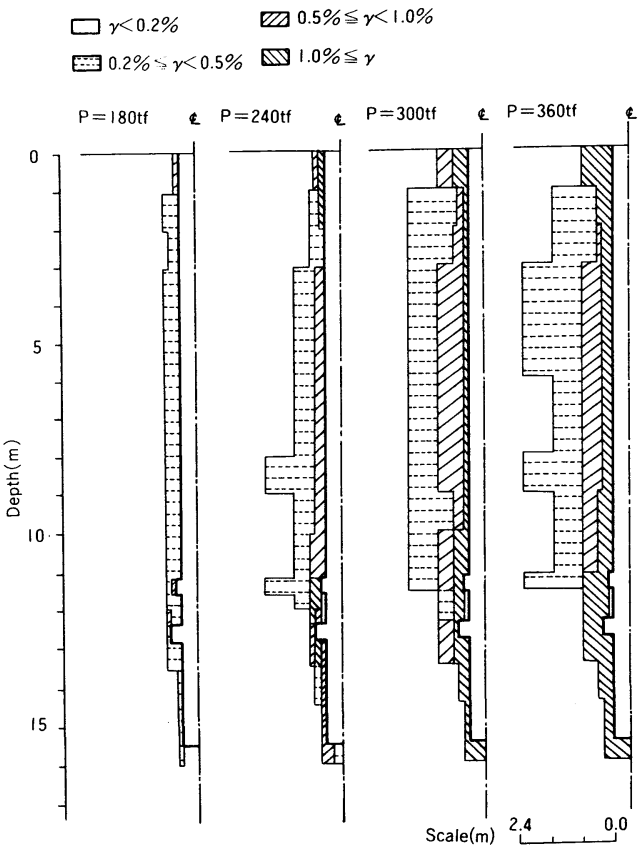

Fig. 9 Simulation for distribution of shear strain in ground.

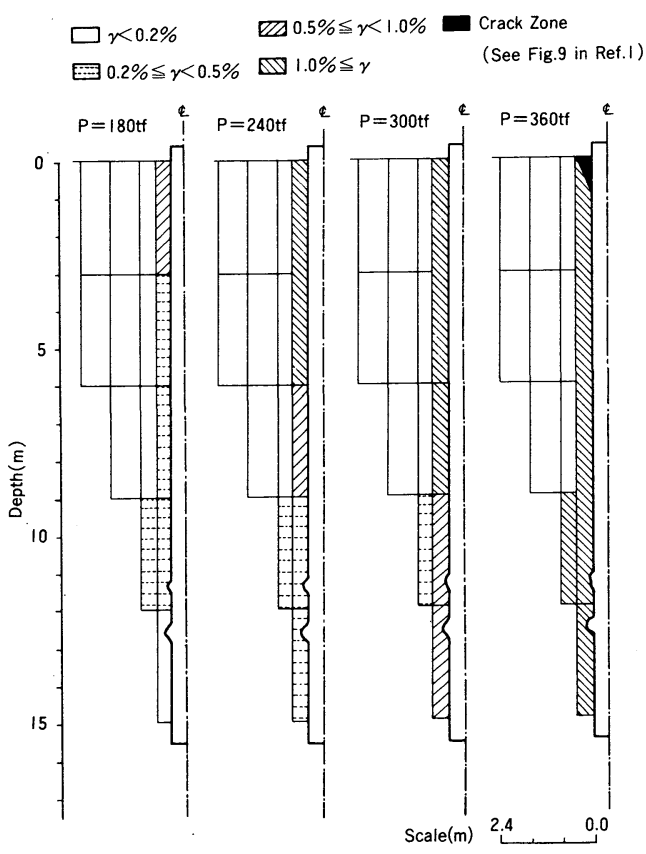

Fig. 10 Distribution of observed shear strain and crack zone in ground. 


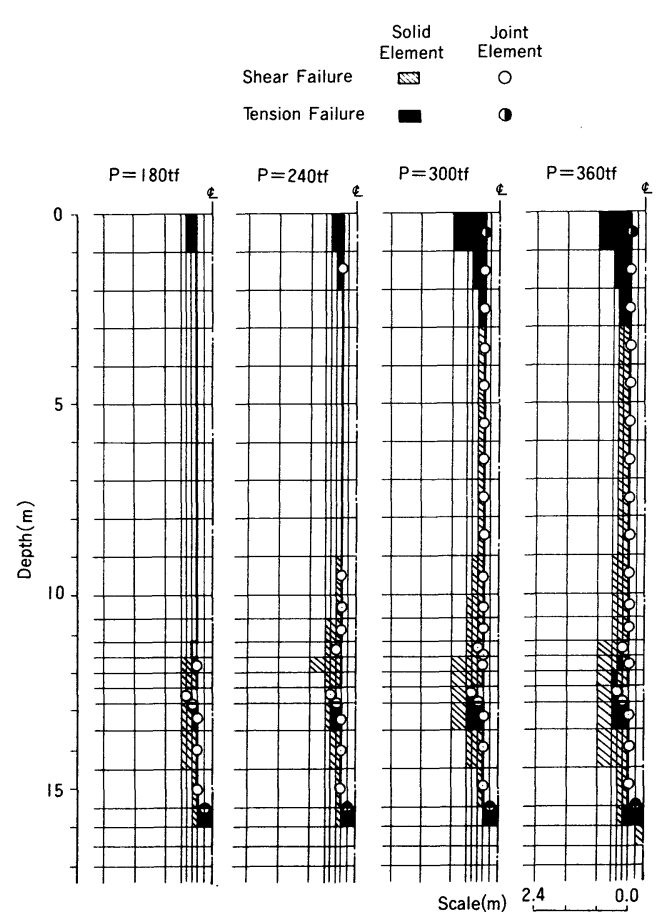

Fig. 11 Simulation for failure zone in ground.

似しているが，連続解析結果は実測値との差が広がって いる. 両解析結果の変位量の差は, 杭と地盤とのずれに よるものであり，最大荷重に近づくと杭と地盤との不連 続変形を無視できないことがうかがえる.

したがって, 設計荷重レベルの変形問題に対しては, 連続解析でも十分な精度が得られるが, 大変形問題に対 しては, 不連続解析が有効と考えられる.

Fig. 9 に不連続解析により得られた杭周辺地盤のせん 断ひずみ分布を示す. Fig. 10 に多段式変位計の実測結 果により，2.で示した方法で求めた「せん断ひずみ」 分布を示す. 両図から，計算結果と実測結果は比較的よ く対応していると判断できる.

Fig. 11 に不連続解析により得られた杭周辺地盤の破 壊領域を示す. 荷重 $180 \mathrm{tf}(1.78 \mathrm{MN})$ で, 地表面付近 の地盤は引張り破壊を生じており, また杭先端付近の杭 周面近傍地盤はせん断破壊を生じている. 荷重の増加に 伴い破壊領域は進展し, 荷重 $300 \mathrm{tf}$ (2.94 MN) で杭の 全長にわたってジョイント部および杭周面近傍地盤が破 壊している. 荷重 $360 \mathrm{tf}$ (3.53 MN) で, 破壊領域はさ らに地中に広がっており，GL-3.0 $\mathrm{m}$ までは引張り破 壊領域がコーン状を呈している. GL-3.0 m 以深では, せん断破壊領域は杭周面から杭半径程度以内の範囲で杭 軸に平行な円筒状を呈している。 また，Fig.10には現 場実験により地表面付近で観測されたクラック領域を示 してある.このコーン状のクラックは, 前論文で示した
ように，引張り破壊により生じたものと想定されたが, 本解析によりそれが裏付けられたものと考えられる.

なお, 連続解析により得られた地盤のせん断ひずみ分 布, 破壊領域もほぼ同様な結果を示している(困は省略).

\section{4. 結論}

場所打ち杭の現場実測結果から，杭に引抜き力が作用 した場合の杭～地盤系の変形・破壊機構に関する基本的 な考察を行った。この結果に基づいて, 有限要素法によ る現場実験のシミュレーションを行い, 杭〜地盤系の引 抜き抵抗機構を数値解析的に検証した. 以下にその結果 を要約する.

（1）実験結果から，土の「せん断ひずみ」に対応す る杭周面摩擦力特性を検証できた。すなわち，杭周面に 作用する摩擦力は, 土の「せん断ひずみ」に対応して増 加し,「せん断ひずみ」が限界値に達すると摩擦力は最 大となり，杭周面近傍地盤にすべりが生じる．今回の実 験における「せん断ひずみ」の限界値は, 粘性土で 0.5 $\sim 0.7 \%$, 砂質土で $1.0 \%$ 程度であった.

（2）実測された周面摩擦力〜「せん断ひずみ」曲線 と土質試験から得られる応力 ひずみ曲線との定量的な 関係を示した。すすなわ，実測せん断弾性係数はおおむ ね $G=4 E_{50} / 2(1+\nu)$ で評価できる.

（３）上記を踏まえ, 地盤材料を非線形弾性体と仮定 し, 有限要素法による現場実験のシミュレーションを 行った.この結果, 杭の変形, 軸力分布ならびに周辺地 盤のひずみ分布の計算值は実測值とよい対応を示し, 引 抜き力を受ける杭～地盤系の挙動の予測法として有限要 素法が妥当なことを示した。

（4）杭の大変形問題に対しては, 杭と地盤との不連 続変形を考慮した有限要素法は有効な方法であるが, 設 計荷重レベルの変形問題に対しては, 通常の連続体モデ ルでも十分な精度が得られることを確認した。

（5）解析結果は, 地表面付近に引張りによるコーン 状の破壊が生じたこと,ならびに地表面付近を除けば, 杭周辺地盤はせん断により破壊し, すべり面は杭周面の ごく近傍の地中に円筒状に生じることを示した．この結 果は, 現場実験結果とよく対応しており, 有限要素法は 周辺地盤の破壊形態の予測法としても妥当であると考え られた。

謝辞：本研究の遂行ならびに本論文の作成にあた り, 暖かいご助言とご指導を賜った京都大学 柴田 徹 博士に深甚な謝意を表する次第である.ささらに，貴重な ご助言を頂いた電力中央研究所 西 好一博士, 東京電 力(株) 江川顕一郎氏ならびに東電設計(株) 佐野俊輔氏 に謝意を表する。 


\section{参考文 献}

1）伊藤圭典・前原雅幸：場所打ち杭の引抜き抵抗に関する 実験之考察, 土木学会論文集, 第 376 号 / III -6, pp. 59 $\sim 67,1986$ 年 12 月.

2) 日本道路協会：道路橋示方書・同解説 (IV下部構造編), 1980.

3) Goodman, R. E., Taylor, R. L. and Brekke, T. L. : A Model for the Mechanics of Jointed Rock, Proc. ASCE., Vol. 94, SM 3, pp. 637 659, 1968.

4）暒谷正孝・済木幸平 : 土の引張り強さの測定について, 第 10 回土質工学研究発表会, pp. 261 264, 1975.

5）佐藤輝行 - 豊岡義則：ロームの引張り強度・変形特性に
ついて, 第 19 回土質工学研究発表会, pp. 467 468, 1984.

6) 土質工学会：土質調査法, 1983.

7) 森 博人・有水恭一：岩盤の力学的定数に関する試験(そ の 2), 日本道路公団試験所報告（昭和 54 年度), pp. 163 $\sim 178,1980$.

8) Uto, K., Maeda, H., Yoshii, Y., Takeuchi, M., Kinoshita, K. and Koga, A. : Horizontal behavior of pier foundations in a shearing type ground model, the 5 th ICONMIG, pp. 115 123, 1985.

（1986.2.14 - 受付） 